\title{
Composition, structure and diversity of fish assemblages across seascape types at Príncipe, an understudied tropical island in the Gulf of Guinea (eastern Atlantic Ocean)
}

\author{
F Otero-Ferrer , F Tuya , NE Bosch Guerra , A Herrero-Barrencua , AD Abreu \& \\ R Haroun
}

To cite this article: F Otero-Ferrer , F Tuya , NE Bosch Guerra , A Herrero-Barrencua , AD Abreu \& R Haroun (2020) Composition, structure and diversity of fish assemblages across seascape types at Príncipe, an understudied tropical island in the Gulf of Guinea (eastern Atlantic Ocean), African Journal of Marine Science, 42:4, 381-391, DOI: 10.2989/1814232X.2020.1826358

To link to this article: https://doi.org/10.2989/1814232X.2020.1826358

\section{曲 Published online: 16 Dec 2020.}

\section{Submit your article to this journal $\longleftarrow$}

Џll Article views: 15

Q View related articles ¿

View Crossmark data $\asymp$ 


\title{
Composition, structure and diversity of fish assemblages across seascape types at Príncipe, an understudied tropical island in the Gulf of Guinea (eastern Atlantic Ocean)
}

\author{
F Otero-Ferrer ${ }^{1 *}$ iD, F Tuya1 iD, NE Bosch Guerra², A Herrero-Barrencua ${ }^{3}$ iD, AD Abreu ${ }^{4}$ iD and R Haroun ${ }^{1}$ iD \\ ${ }^{1}$ Biodiversity and Conservation Research Group, IU-ECOAQUA, Universidad de Las Palmas de Gran Canaria, Marine \\ Scientific and Technological Park, Telde, Gran Canaria, Canary Islands \\ 2 UWA Oceans Institute, The University of Western Australia, Perth, Australia \\ ${ }^{3}$ Elittoral s.n.I.e., Scientific and Technological Park, Las Palmas, Gran Canaria, Canary Islands \\ ${ }^{4}$ Island of Príncipe Biosphere Reserve, Santo António, São Tomé, Democratic Republic of São Tomé and Príncipe \\ *Corresponding author, e-mail: francesco_25@hotmail.com
}

\begin{abstract}
Coastal seascapes are often composed of a mosaic of interconnected habitats. Transitions between adjacent habitats are of special relevance to the ecology of many reef-associated organisms. In this study, we tested (i) whether the degree of similarity in the composition and structure of coastal fish assemblages differed between three interconnected seascape types, and (ii) whether differences in taxonomic and phylogenetic diversity of the fish assemblages were consistent between the seascape types. We sampled fish species from diverse habitats in the shallow coastal waters surrounding the island of Príncipe (Gulf of Guinea, eastern Atlantic Ocean), an understudied and remote tropical island. Specifically, video transects were carried out by SCUBA divers at three seascape types: rocky reefs, rocky reef-rhodolith bed transitions, and rocky reef-sandy bottom transitions, to extract presence/absence and ordinal abundance data, across a range of depths (9-31 $\mathrm{m}$ ), covering the entire perimeter of the island. A total of 71 fish taxa were recorded. Both the composition and structure of the fish assemblages differed between the studied seascapes. The mean number of fish species (taxonomic diversity) was higher on 'reefs' than in both the 'reef-rhodolith bed' and 'reef-sandy bottom' transitions. In contrast, the taxonomic distinctness index (phylogenetic diversity) was higher for fish assemblages in both transitional seascape types than on rocky reefs. Hence, at the island-scale, the protection of local fish assemblages needs to consider a representative network of interconnected habitats, including at these seascapes boundaries where important ecological functions seem to occur.
\end{abstract}

Keywords: biodiversity, conservation, ecotones, equatorial West Africa, ichthyofauna, tropical reefs, underwater video, Wallacean shortfall

Introduction

Coastal landscapes, or seascapes, typically include a collection of reticulated habitats, such as rocky reefs, coral reefs, seagrass meadows, rhodolith beds and sandy seabeds, which create a complex matrix of habitat patches (Dorenbosch et al. 2005; Tuya et al. 2010; Cresswell et al. 2017). The abundance and composition of nearshore species is markedly influenced by the arrangement of such habitats, including the spatial distribution of fish associated with both hard and soft bottoms (Guidetti 2000; Tuya et al. 2010; Campbell et al. 2011; Espino et al. 2015). Notably, transitions between adjacent habitats-including edges or ecotones-are conspicuous seascape elements of coastal environments which alter the distributions and abundances of associated ichthyofauna (Valentine et al. 2008; Tuya et al. 2010; Espino et al. 2015). For example, several studies have documented differences in fish assemblage structure between reefs and surrounding sandy areas, in both tropical and temperate realms (Guidetti 2000; Mateo and Tobias 2007; Campbell et al. 2011). Typically, higher abundance and species richness (taxonomic diversity) are found on reefs than on adjacent sandy bottoms (Barros et al. 2001; Mateo and Tobias 2007). However, we have limited knowledge on how other biodiversity facets (e.g. phylogenetic diversity) vary across habitat types (Bosch et al. 2017; Tuya et al. 2018), and to what extent there are spatial congruencies and/or mismatches among biodiversity facets at a range of spatial scales (Tucker et al. 2017; Wong and Kay 2019).

Within coastal seascapes, rhodolith-dominated areas and sandy seabeds are interspersed across temperate and tropical seas, and typically arranged in mosaics with rocky reefs (Otero-Ferrer et al. 2019). Rhodolith beds are underpinned by free-living, non-geniculate, calcareous red algae (Rhodophyta), which form nodules of rugged appearance and diverse morphology (Amado-Filho et al. 2007; Foster et al. 2013). Extensive rhodolith beds are found in many of the world's coastal areas (Amado-Filho et al. 2007; Foster et al. 2013), sustaining diverse invertebrate assemblages through the provisioning of food resources and refuges (Steller et al. 2003; de Figueiredo 
et al. 2007; Otero-Ferrer et al. 2019, 2020). Although invertebrate assemblages associated with rhodolith beds have been extensively described (Grall et al. 2006; Amado-Filho et al. 2007; Foster et al. 2013), fish species living in these habitats are mostly unknown from an ecological perspective (Pereira-Filho et al. 2015).

Descriptions of local flora and fauna are key for understudied regions of the world's oceans, especially in species-rich tropical coastal areas (Alexandre et al. 2017; Haroun et al. 2018; Tuya et al. 2018; Vasco-Rodrigues et al. 2018). In this sense, filling knowledge gaps regarding the presence of species and their associated distribution patterns (the so-called Wallacean shortfall) might help to unravel large-scale biodiversity patterns, optimising transnational conservation planning (Whittaker et al. 2005; Bini et al. 2006; Hortal et al. 2015). This is the case regarding tropical western African coasts, including the Gulf of Guinea, which, despite being considered hotspots of marine biodiversity (Roberts et al. 2002), have many scientific gaps. From a biogeographic perspective, this tropical region is particularly relevant because the eastern and western Atlantic marine faunas are connected through the eastward-flowing Equatorial Counter Current (Wirtz et al. 2007).

The island of Príncipe (Democratic Republic of São Tomé and Príncipe) is a small tropical island $\left(\sim 136 \mathrm{~km}^{2}\right)$ near the equator, located within the Gulf of Guinea Islands marine ecoregion (eastern Atlantic Ocean) (Spalding et al. 2007), and was added to UNESCO's World Network of Biosphere Reserves in 2012. The island is understudied in terms of marine biodiversity, relative to its terrestrial flora and fauna (Jones 1994; Daniel 2010; Miller et al. 2012; Bell et al. 2015). Despite this, some fish inventories are available (e.g. Afonso et al. 1999; Wirtz et al. 2007; Maia et al. 2019), including a recent report of 130 fish species (Vasco-Rodrigues et al. 2018). These works, however, are based mostly on information collected from nearby São Tomé Island (Maia et al. 2019). The only quantitative study conducted in nearshore habitats of Príncipe was published recently by Tuya et al. (2018), focusing on changes in the diversity of reef-fish assemblages across depth gradients.

In this study, we surveyed nearshore fish species at three conspicuous seascape types across shallow coastal waters of Príncipe: rocky reefs, rocky reef-rhodolith bed transitions, and rocky reef-sandy bottom transitions. We used underwater video recordings made while SCUBA diving to determine (i) whether the degree of similarity in the composition and structure of fish assemblages differed between the three seascape types, and (ii) whether differences in taxonomic and phylogenetic diversity of fish assemblages were consistent between these habitats. We hypothesised that fish biodiversity, in terms of 'how much' taxonomic and phylogenetic diversity exists, would differ between the three habitats. In particular, we expected greater diversity on rocky reefs relative to the habitat transitions. Such baseline information is pertinent to promote conservation planning through the future establishment of marine protected areas within the framework of the UNESCO-designated Island of Príncipe Biosphere Reserve, especially since coastal resources targeted by local fisheries in the São Tomé and Príncipe islands have recently experienced declines in the abundance and mean body size of captures (Maia et al. 2018).

\section{Materials and methods}

\section{Study area}

The island of Príncipe (Figure 1) hosts a range of marine shallow-water (0-30 m depth) habitats, such as rocky reefs with sparse coral outcrops, sandy bottoms, and rhodolith biogenic beds (locally known as gla-gla) (Abreu et al. 2017; Maia et al. 2018). Rocky reefs have an irregular topography, including high-relief elements such as crevices, overhangs and caves (Lee et al. 2011; Carvalho et al. 2013). A total of 12 subtidal sites, along the island's entire perimeter, were surveyed in October and November of 2016 (Table 1), covering a depth range of 9-31 m. The sites encompassed a range of interspersed habitats, including rocky reefs adjacent to both rhodolith beds and sandy bottoms. Coralline algae and fleshy macroalgae dominated the benthic community structure on reefs, with sparse representation of filter-feeder colonies (e.g. sponges, and soft and hard corals) (Abreu et al. 2017). For the purpose of this study, we typified these habitat mosaics according to three seascape types: (i) transitions (incorporating edges) between rocky reefs and rhodolith beds; (ii) transitions (incorporating edges) between rocky reefs and sandy bottoms; and (iii) reefs (rocky reef areas $>30 \mathrm{~m}$ from habitat edges) (Figure 2).

\section{Fieldwork and data processing}

Video transects with underwater cameras (GoPro7 Black, GoPro Inc., USA) were carried out by a SCUBA diver, swimming at a constant speed for $8 \mathrm{~min}, \sim 1 \mathrm{~m}$ above the bottom (wide-angle shooting at $133.9^{\circ}$ diagonal field of view), at each of the three seascape types per site, if available. Video recordings are a useful method to extract presence/absence and ordinal abundance data on fish assemblages, avoiding in situ misidentifications of the relatively poorly known fauna of the region. Between two and six transects (samples) were carried out per seascape type and site, depending on their extent and availability as well as the intrinsic limitations of SCUBA diving with depth (Table 1). In the laboratory, each video was visualised three times using VLC 2.1+ software, which allows for light adjustments to improve fish identification. Fish species were identified following available checklists from São Tomé and Príncipe (i.e. Afonso et al. 1999; Wirtz et al. 2007; Vasco-Rodrigues et al. 2018). Only videos with a seawater visibility of $>10 \mathrm{~m}$ were considered valid, for a total of 62 transects (14 for rocky reef-rhodolith transitions, 37 for rocky reef-sand transitions, and 11 for rocky reefs), equivalent to $10 \mathrm{~h}$ and $18 \mathrm{~min}$ of underwater observations. Individual fish that were distant from the camera, or appeared briefly and were blurred, were not considered. Some fish were not visually identified to species level, but were recorded at the genus level (i.e. Kyphosus spp., Gobius spp., Lutjanus spp. and Thunnus spp.) or family level (Pomacentridae). Each video was annotated with the depth $(\mathrm{m})$ of the recording. From each video, we extracted two types of data: (i) a presence/ absence list (compositional data), and (ii) abundance 


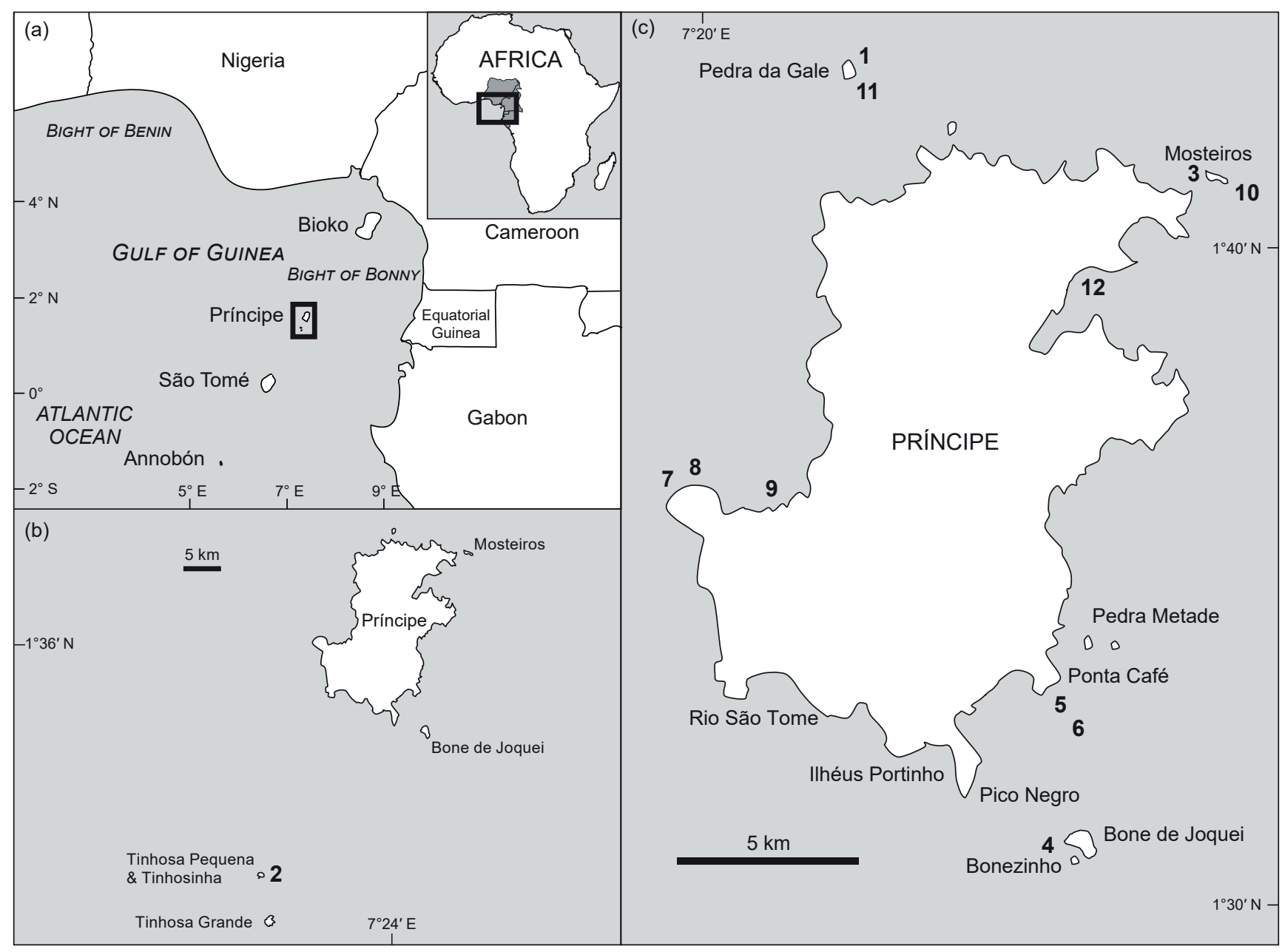

Figure 1: (a) Locations of the island of Príncipe in the Gulf of Guinea and (b, c) the sampled sites around the perimeter of the island: 1 - Pedra Galé; 2 - Ilhas Tinhosas; 3 - Mosteiros Oeste; 4 - Boné de Jóquei; 5 - Pedra Metade 1; 6 - Pedra Metade 2; 7 - Baía das Agulhas 1; 8 - Focinho de Cão; 9 - Baía das Agulhas 2; 10 - Mosteiros Este; 11 - Pedra Galé Sul; 12 - Pedra Medónia

Table 1: Location and depth of study sites at the island of Príncipe, Gulf of Guinea, for a survey of fish assemblages, in October to November 2016

\begin{tabular}{lclll}
\hline Date & Depth $(\mathrm{m})$ & \multicolumn{1}{c}{ Site } & \multicolumn{1}{c}{ Latitude } & \multicolumn{1}{c}{ Longitude } \\
\hline 30 Oct 2016 & 31 & Pedra Galé & $1^{\circ} 43^{\prime} 35.45^{\prime \prime} \mathrm{N}$ & $7^{\circ} 22^{\prime} 45.84^{\prime \prime} \mathrm{E}$ \\
31 Oct 2016 & 20 & Ilhas Tinhosas & $1^{\circ} 23^{\prime} 1.13^{\prime \prime} \mathrm{N}$ & $7^{\circ} 17^{\prime} 0.80^{\prime \prime} \mathrm{E}$ \\
1 Nov 2016 & 9 & Mosteiros Oeste & $1^{\circ} 41^{\prime} 4.34^{\prime \prime} \mathrm{N}$ & $7^{\circ} 28^{\prime} 3.17^{\prime \prime} \mathrm{E}$ \\
3 Nov 2016 & 13 & Boné de Jóquei & $1^{\circ} 30^{\prime} 52.08^{\prime \prime} \mathrm{N}$ & $7^{\circ} 25^{\prime} 30.65^{\prime \prime} \mathrm{E}$ \\
4 Nov 2016 & 12 & Pedra Metade 1 & $1^{\circ} 33^{\prime} 5.25^{\prime \prime} \mathrm{N}$ & $7^{\circ} 25^{\prime} 9.67^{\prime \prime} \mathrm{E}$ \\
5 Nov 2016 & 18 & Pedra Metade 2 & $1^{\circ} 33^{\prime} 0.80^{\prime \prime} \mathrm{N}$ & $7^{\circ} 25^{\prime} 19.82^{\prime \prime} \mathrm{E}$ \\
6 Nov 2016 & 22 & Baía das Agulhas 1 & $1^{\circ} 36^{\prime} 9.25^{\prime \prime} \mathrm{N}$ & $7^{\circ} 20^{\prime} 45.94^{\prime \prime} \mathrm{E}$ \\
6 Nov 2016 & 17 & Focinho de Cão & $1^{\circ} 36^{\prime} 33.53^{\prime \prime} \mathrm{N}$ & $7^{\circ} 20^{\prime} 1.23^{\prime \prime} \mathrm{E}$ \\
7 Nov 2016 & 15 & Baía das Agulhas 2 & $1^{\circ} 36^{\prime} 7.82^{\prime \prime} \mathrm{N}$ & $7^{\circ} 21^{\prime} 10.00^{\prime \prime} \mathrm{E}$ \\
8 Nov 2016 & 13 & Mosteiros Este & $1^{\circ} 41^{\prime} 5.34^{\prime \prime} \mathrm{N}$ & $7^{\circ} 28^{\prime} 12.63^{\prime \prime} \mathrm{E}$ \\
9 Nov 2016 & 21 & Pedra Galé Sul & $1^{\circ} 43^{\prime} 26.04^{\prime \prime} \mathrm{N}$ & $7^{\circ} 22^{\prime} 49.92^{\prime \prime} \mathrm{E}$ \\
10 Nov 2016 & 21 & Pedra Medónia & $1^{\circ} 41^{\prime} 29.24^{\prime \prime} \mathrm{N}$ & $7^{\circ} 26^{\prime} 19.25^{\prime \prime} \mathrm{E}$ \\
\hline
\end{tabular}

information for each fish taxon, by considering five ordinal categories of abundance: $1=>150$ ind. per transect; $2=71-150$ ind. per transect; $3=41-70$ ind. per transect; $4=21-40$ ind. per transect; $5=1-20$ ind. per transect (Bosch et al. 2017).

\section{Diversity estimates}

Two indices capturing complementary aspects of the diversity of local communities (alpha-diversity) were calculated for each transect, according to the composition data (presence/absence) and assemblage structure 


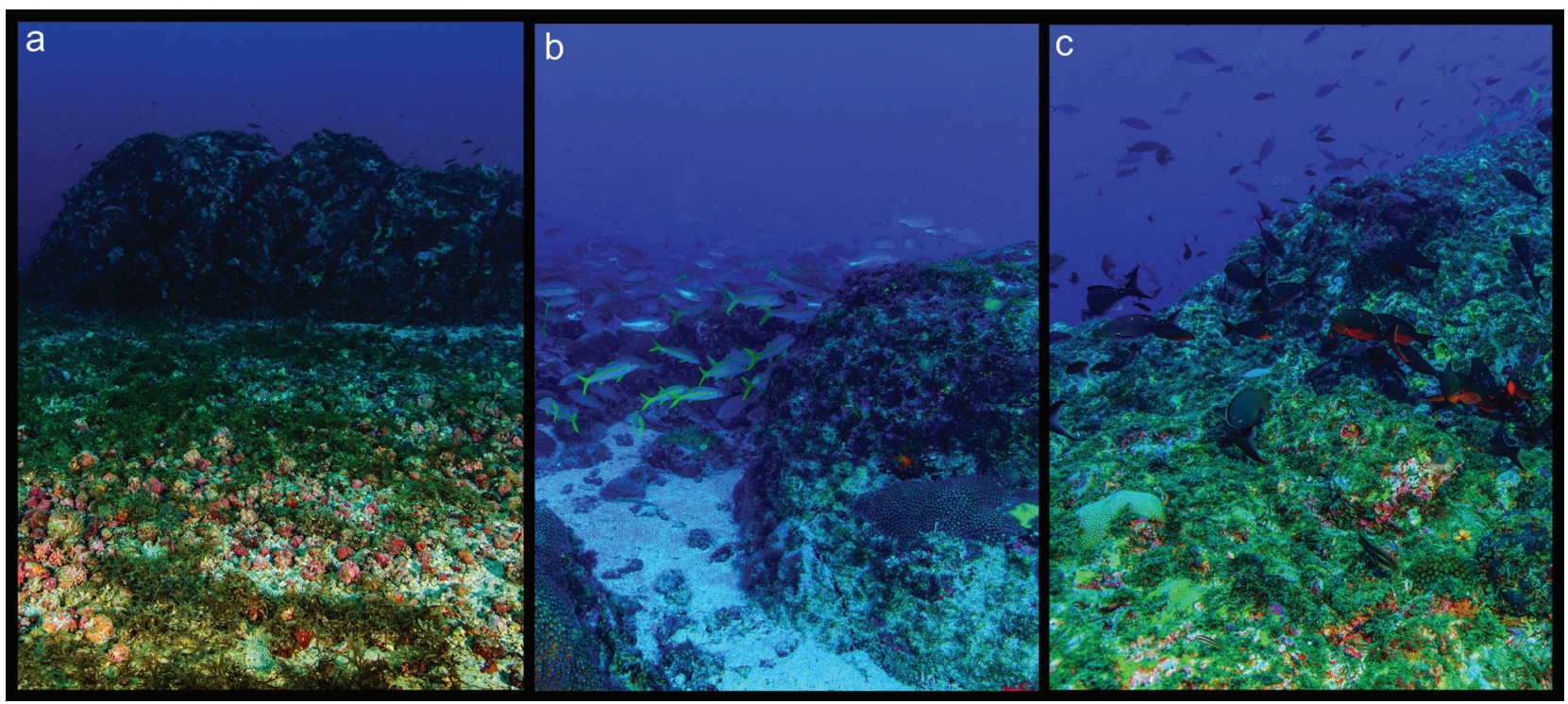

Figure 2: Seascape types at the island of Príncipe, surveyed during this study: (a) transitions between rocky reefs and rhodolith beds; (b) transitions between rocky reefs and sandy bottoms; (c) rocky reefs

data (composition and ordinal abundance). Taxonomic diversity (TD) was assessed through species richness (the number of fish taxa), whereas phylogenetic diversity was assessed through an index of taxonomic distinctness, $\Delta^{*}$ (Clarke and Warwick 2001). This index considers the taxonomic distances along a Linnean classification tree between every pair of individuals drawn at random from the local community. The identification of fishes was initially validated via the World Register of Marine Species (WoRMS) 'match taxa' tool (www.marinespecies.org) and the available checklists for the nearby tropical areas (Afonso et al. 1999; Wirtz et al. 2007; Maia et al. 2019). The R package 'EcolndR' (Guisande González 2017) implemented in R statistical software (R Core Team 2016) was further used to compute these two metrics of diversity. Phylogenetic diversity indices provided much greater resolution than traditional diversity indices, incorporating information on the 'relatedness' of species based on their evolutionary history (Cadotte et al. 2010). Increasingly used in conservation and ecology (Rogers et al. 1999; Ellingsen et al. 2005; Cadotte et al. 2010, 2012), their values are independent of the sampling effort, allowing objective comparisons between sites from studies where sampling effort is not standardised (Rogers et al. 1999).

\section{Statistical analysis}

Canonical analysis of principal coordinates (CAP) (Anderson and Willis 2003), implemented in PRIMER 6 (Clarke and Warwick 2001), was used as a constrained ordination to visualise differences in assemblage composition (i.e. according to presence/absence data) and structure (i.e. according to ordinal abundance categories) between the seascape types. By using CAP, axes were found in the multivariate space to maximise the separation between seascape types. Analyses were based on Jaccard and Bray-Curtis dissimilarities, which are ideal for compositional (presence/absence) and abundance data, respectively (Clarke and Warwick 2001). The CAP routine also calculated miscalculation errors using the 'leave-one-out allocation' success (LoA): each sample was removed from the dataset, the CAP analysis re-run using the remaining observations, and then the removed sample classified to the nearest group centroid in the canonical space. Comparison of known groups with allocated groups provided miscalculation errors (Anderson and Willis 2003).

Generalised linear models (GLMs), using a negative binomial family-error structure because of overdispersion resulting from a large number of zeros, were fitted to both the matrices of species composition and species (ordinal) abundances via the $\mathrm{R}$ package 'mvabund' (Wang et al. 2012). The middle points of the five ordinal categories of abundance were considered. The depth of each video record was included in the models as a covariate. We tested the multivariate hypotheses that the composition and assemblage structure of fishes varied between habitats using the 'anova' function, which provided an analysis of deviance table. Probability values were then calculated using 999 resampling iterations via PIT-trap resampling. Diagnosis plots of residuals were visually inspected to check the appropriateness of fitted GLMs. Finally, GLMs were also fitted to both fish species richness and taxonomic distinctness, using the $\mathrm{R}$ package 'MASS' (Venables and Ripley 2002), to test for differences in species richness and taxonomic distinctness between seascape types. Poisson and Gamma family error structures, both with a log-link function, were selected to reach linear assumptions, respectively.

\section{Results}

A total of 71 fish taxa were recorded in this study (Table 2), which included the identification of 62 species, 59 genera and 35 families. Nearly half of the taxa (44\%) were recorded in all three seascape types; $\sim 30 \%$ of the taxa occurred in 
Table 2: Checklist of fish taxa identified on each of the three seascapes types surveyed at the island of Príncipe ( 1 = present; $0=$ absent), including the category of each species on the IUCN Red List of Threatened Species (DD = Data Deficient; LC = Least Concern; VU = Vulnerable)

\begin{tabular}{|c|c|c|c|c|}
\hline Species & $\begin{array}{l}\text { Rocky reef-rhodolith } \\
\text { bed transitions }\end{array}$ & $\begin{array}{l}\text { Rocky reef-sandy } \\
\text { bottom transitions }\end{array}$ & Rocky reefs & $\begin{array}{l}\text { IUCN Red List } \\
\text { category }\end{array}$ \\
\hline Abudefduf hoefleri & 1 & 1 & 0 & $\mathrm{DD}$ \\
\hline Abudefduf saxatilis & 0 & 1 & 1 & LC \\
\hline Acanthurus monroviae & 1 & 1 & 1 & LC \\
\hline Aluterus scriptus & 0 & 0 & 1 & LC \\
\hline Antennarius sp. & 0 & 1 & 0 & - \\
\hline Apletodon wirtzi & 0 & 1 & 0 & LC \\
\hline Apogon pseudomaculatus & 0 & 1 & 1 & LC \\
\hline Balistes punctatus & 1 & 1 & 1 & VU \\
\hline Bodianus pulchellus & 1 & 1 & 1 & LC \\
\hline Bodianus speciosus & 1 & 1 & 1 & $\mathrm{DD}$ \\
\hline Boops boops & 0 & 1 & 0 & LC \\
\hline Bothus guibei & 1 & 0 & 0 & $\mathrm{DD}$ \\
\hline Cantherhines pullus & 1 & 1 & 1 & LC \\
\hline Canthidermis sufflamen & 0 & 1 & 1 & LC \\
\hline Canthigaster supramacula & 1 & 1 & 1 & LC \\
\hline Carangoides bartholomaei & 1 & 1 & 1 & LC \\
\hline Caranx lugubris & 1 & 0 & 1 & LC \\
\hline Cephalopholis nigri & 0 & 1 & 1 & LC \\
\hline Cephalopholis taeniops & 1 & 1 & 1 & LC \\
\hline Chaetodon robustus & 0 & 0 & 1 & LC \\
\hline Chilomycterus reticulatus & 0 & 0 & 1 & LC \\
\hline Chromis cadenati & 1 & 0 & 0 & LC \\
\hline Chromis limbata & 1 & 1 & 1 & LC \\
\hline Chromis multilineata & 1 & 1 & 0 & LC \\
\hline Cirrhitus atlanticus & 1 & 1 & 1 & LC \\
\hline Clepticus africanus & 1 & 1 & 1 & DD \\
\hline Coris atlantica & 1 & 1 & 1 & LC \\
\hline Echeneis naucrates & 1 & 0 & 0 & LC \\
\hline Elagatis bipinnulata & 1 & 1 & 1 & LC \\
\hline Epinephelus adscensionis & 1 & 1 & 0 & LC \\
\hline Gobius spp. & 1 & 1 & 1 & - \\
\hline Ginglymostoma cirratum & 1 & 1 & 0 & DD \\
\hline Gnatholepis thompsoni & 1 & 1 & 1 & LC \\
\hline Gorogobius nigricinctus & 1 & 1 & 0 & LC \\
\hline Heteropriacanthus cruentatus & 1 & 0 & 1 & LC \\
\hline Hippocampus algiricus & 0 & 1 & 0 & VU \\
\hline Holacanthus africanus & 1 & 1 & 1 & LC \\
\hline Holocentrus adscensionis & 1 & 1 & 1 & LC \\
\hline Kyphosus spp. & 1 & 1 & 1 & - \\
\hline Lutjanus spp. & 1 & 1 & 1 & - \\
\hline Lutjanus agennes & 0 & 1 & 1 & DD \\
\hline Lutjanus fulgens & 0 & 1 & 0 & LC \\
\hline Melichthys niger & 0 & 1 & 0 & LC \\
\hline Microspathodon frontatus & 0 & 1 & 1 & LC \\
\hline Myrichthys pardalis & 0 & 1 & 1 & LC \\
\hline Myripristis jacobus & 1 & 1 & 1 & LC \\
\hline Mulloidichthys martinicus & 1 & 1 & 1 & LC \\
\hline Muraena spp. & 0 & 1 & 1 & - \\
\hline Muraena melanotis & 0 & 1 & 1 & LC \\
\hline Oblada melanura & 1 & 1 & 1 & LC \\
\hline Ophioblennius atlanticus & 1 & 1 & 1 & LC \\
\hline Paranthias furcifer & 1 & 1 & 1 & LC \\
\hline Pomacentridae & 1 & 1 & 1 & - \\
\hline Pomadasys incisus & 0 & 1 & 0 & LC \\
\hline Prionurus biafraensis & 1 & 1 & 1 & LC \\
\hline Rypticus saponaceus & 1 & 1 & 0 & LC \\
\hline Sargocentron hastatum & 0 & 1 & 0 & LC \\
\hline Scarus hoefleri & 1 & 1 & 1 & LC \\
\hline Scorpaena laevis & 0 & 1 & 0 & DD \\
\hline Seriola rivoliana & 0 & 1 & 0 & LC \\
\hline Serranus sp. & 1 & 1 & 0 & - \\
\hline Sparisoma spp. & 1 & 1 & 1 & - \\
\hline Sparisoma choati & 1 & 1 & 1 & - \\
\hline Sparisoma rubripinne & 0 & 1 & 0 & LC \\
\hline Sphyraena barracuda & 1 & 1 & 1 & LC \\
\hline Stegastes imbricatus & 1 & 1 & 0 & LC \\
\hline Taeniura grabata & 1 & 1 & 0 & $\mathrm{DD}$ \\
\hline Thalassoma newtoni & 1 & 1 & 1 & LC \\
\hline Thunnus spp. & 1 & 0 & 0 & - \\
\hline Wheelerigobius wirtzi & 0 & 1 & 1 & LC \\
\hline Xyrichtys novacula & 1 & 0 & 0 & LC \\
\hline
\end{tabular}


two seascape types; and $\sim 27 \%$ of the taxa were restricted to a particular seascape (Figure 3 ). Rocky reefs and reefsandy bottom transitions shared the greatest number of taxa (9), together with reef-sandy bottom transitions and reef-rhodolith bed transitions (9), when compared with rocky reefs and reef-rhodolith transitions (2) (Figure 3).

Both the composition and structure of fish assemblages differed between the three seascapes types (analysis of deviance: $\operatorname{dev}=182.49, p=0.002$, df $=2$; dev $=184.23$, $p=0.01$, df $=1$, respectively) (Table 3 ). In particular, fishes associated with reef-rhodolith bed transitions differed

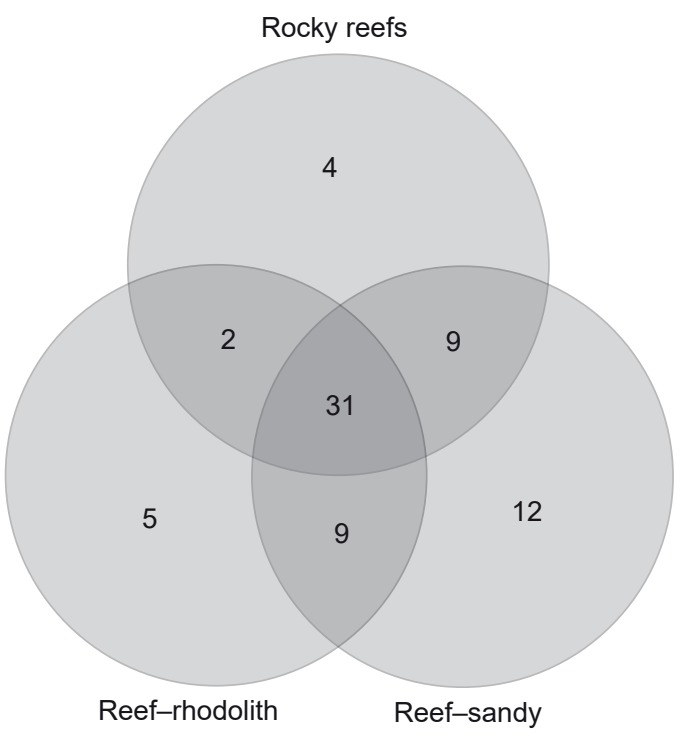

Figure 3: Venn diagram showing the overlap in fish species composition in three nearshore seascape types surveyed at the island of Príncipe: reef-rhodolith $=$ transitions between rocky reefs and rhodolith beds; reef-sandy = transitions between rocky reefs and sandy bottoms; and rocky reefs significantly in terms of both composition and assemblage structure to fishes from reef-sandy bottom transitions $($ Wald value $=5.66, p=0.03 ;$ Wald value $=7.12, p=0.03$, respectively) (Table 4 ). However, though fishes from reefsandy bottom transitions and rocky reefs differed in terms of their composition (Wald value $=6.09, p=0.02$ ), they did not differ in terms of their assemblage structure (Wald value $=$ 5.18, $p=0.51$ ) (Table 4).

These multivariate patterns are visualised in the CAP ordinations (Figure 4); samples corresponding to reefrhodolith bed transitions cluster on the left-hand side of both ordinations, whereas samples corresponding to rocky reefs are on the right-hand side of both ordinations. Fish assemblages associated with reef-sandy bottom transitions are scattered across the entire ordination space.

Samples from rocky reefs had the lowest misclassification of the three seascape types $(72.72 \%$ of corrected allocations, in terms of both fish composition and assemblage structure) (Table 5); when misclassified, all samples from rocky reefs were considered to be from reef-sandy bottom transitions. In contrast, samples from reef-rhodolith bed transitions had the larger degree of misclassification $(57.14 \%$ and $50.0 \%$ of corrected allocations, respectively) (Table 5); when misclassified, samples from reef-rhodolith bed transitions were assigned primarily to reef-sandy bottom transitions (Table 5).

The mean number of fish species (species richness) per sample was larger on rocky reefs than in both reef-rhodolith beds and reef-sandy bottom transitions (GLM: estimate $=0.21, p=0.02$ ) (Figure 5a; Table 6). However, the taxonomic distinctness of fish assemblages was higher for both transition types relative to rocky reefs (GLM: estimate $=-0.17, p=0.08$ ) (Figure 5b; Table 6).

\section{Discussion}

This study shows that the composition, assemblage structure and diversity of coastal fishes at Príncipe differed between

Table 3: Analysis of deviance testing the multivariate hypotheses that the composition and assemblage structure of fishes differed between the three landscape types, across a range of depths, at the island of Príncipe. $\mathrm{df}=$ degrees of freedom

\begin{tabular}{|c|c|c|c|c|c|c|}
\hline \multirow{2}{*}{ Factor } & \multirow{2}{*}{$\mathrm{df}($ Residual) } & \multirow{2}{*}{$\mathrm{df}$} & \multicolumn{2}{|c|}{ Composition } & \multicolumn{2}{|c|}{ Assemblage structure } \\
\hline & & & Deviation & $p$-value & Deviation & $p$-value \\
\hline Intercept & 61 & & & & & \\
\hline Depth & 60 & 1 & 93.99 & 0.006 & 96.52 & 0.001 \\
\hline Habitat & 58 & 2 & 182.49 & 0.002 & 184.23 & 0.01 \\
\hline
\end{tabular}

Table 4: Results of multivariate generalised linear models predicting differences in the composition and assemblage structure of fishes between the three habitat types, across a range of depths, at the island of Príncipe. The reference level is 'reef-sandy' transitions

\begin{tabular}{lcccc}
\hline \multirow{2}{*}{ Factor } & \multicolumn{2}{c}{ Composition } & \multicolumn{2}{c}{ Assemblage structure } \\
\cline { 2 - 5 } & Wald value & $p$-value & Wald value & $p$-value \\
\hline Intercept & 10.56 & 0.001 & 13.10 & 0.001 \\
Depth & 7.35 & 0.08 & 10.85 & 0.05 \\
Habitat [reef-rhodolith transitions] & 5.66 & 0.03 & 7.12 & 0.03 \\
Habitat [rocky reefs] & 6.09 & 0.02 & 5.18 & 0.51 \\
\hline
\end{tabular}


three types of nearshore seascapes. The two biodiversity dimensions we studied-taxonomic and phylogenetic diversity-both showed differences between the habitats.

Among the fish species recorded, some are listed as Vulnerable and others as Data Deficient on the

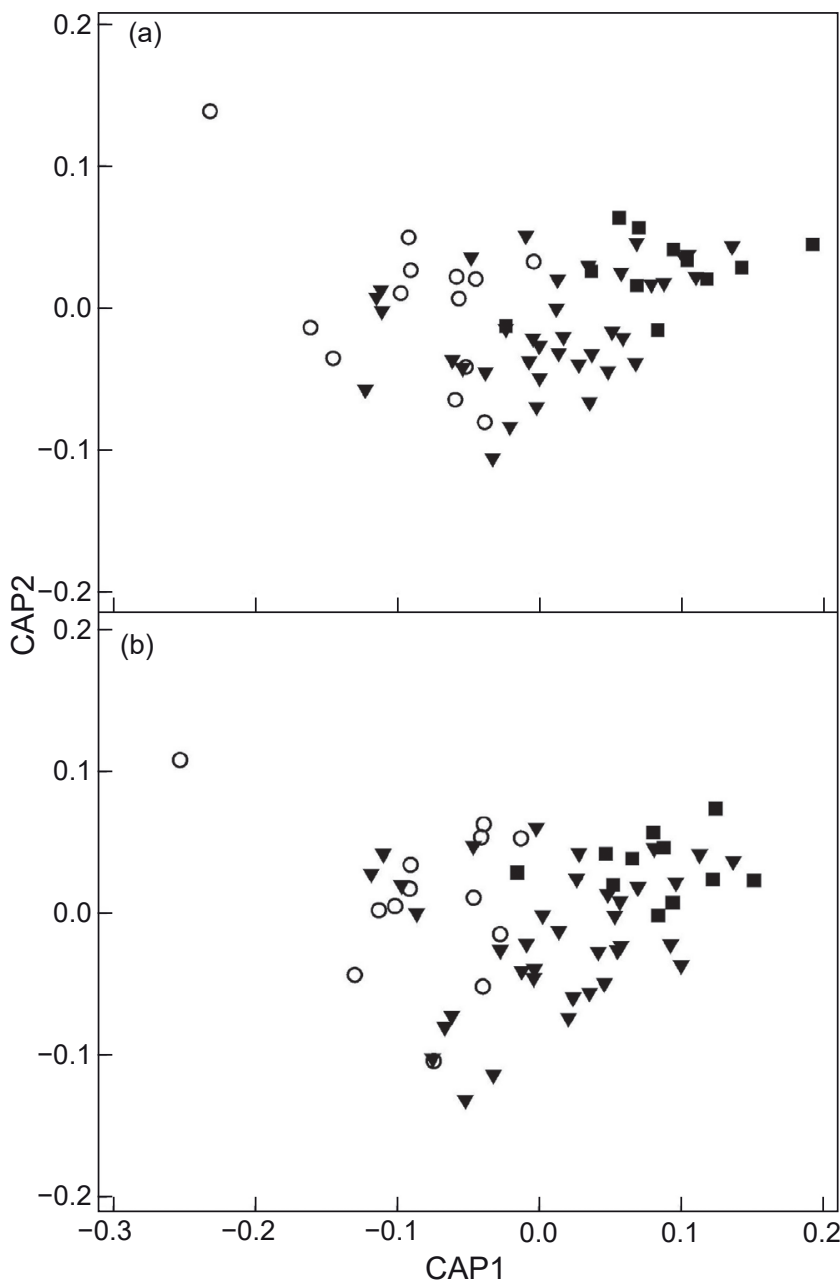

Figure 4: Canonical analysis of principal coordinates (CAP) bidimensional ordinations denoting differences in (a) fish composition and (b) fish assemblage structure, between seascape types in nearshore waters of the island of Príncipe. $\circ=$ reefrhodolith bed transitions; $\boldsymbol{\nabla}=$ reef-sandy bottom transitions; - = rocky reefs
IUCN Red List of Threatened Species, including, respectively, a heavily traded species of seahorse (Hippocampus algiricus) (Otero-Ferrer et al. 2017) and an economically important and probably overfished shark species (Ginglymostoma cirratum) (Maia et al. 2018). Our data highlight the need for additional biological

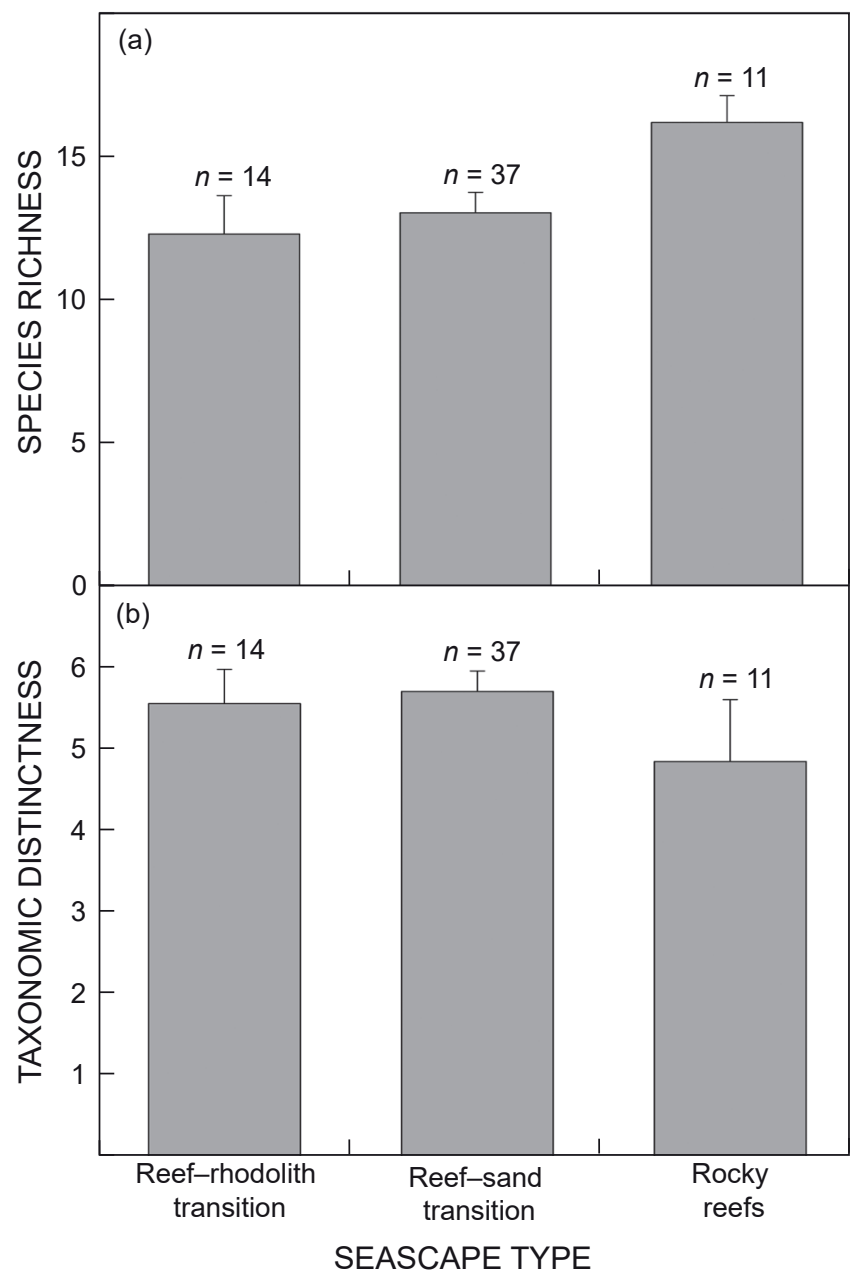

Figure 5: Differences in (a) fish species richness and (b) taxonomic distinctness between seascape types in nearshore waters of the island of Príncipe. Error bars represent $+\mathrm{SE} ; n=$ number of underwater video transects

Table 5: Miscalculation errors (cross-validation), using the 'leave-one-out allocation' success, of samples according to their composition and assemblage structure, collected from each of three seascape types sampled at the island of Príncipe

\begin{tabular}{|c|c|c|c|c|c|c|c|}
\hline Original group & Reef-rhodolith & Reef-sandy & Rocky reefs & Total & $\%$ Success & Total correct & $\begin{array}{c}\text { Misclassification } \\
\text { error }\end{array}$ \\
\hline \multicolumn{8}{|c|}{ Composition } \\
\hline Reef-rhodolith & 8 & 6 & 0 & 14 & 57.14 & $38 / 62(61.29 \%)$ & $38.71 \%$ \\
\hline Reef-sandy & 6 & 22 & 9 & 37 & 59.46 & & \\
\hline Rocky reefs & 0 & 3 & 8 & 11 & 72.73 & & \\
\hline \multicolumn{8}{|c|}{ Assemblage structure } \\
\hline Reef-rhodolith & 7 & 6 & 1 & 14 & 50 & $37 / 62(59.68 \%)$ & $40.32 \%$ \\
\hline Reef-sandy & 5 & 22 & 10 & 37 & 59.46 & & \\
\hline Rocky reefs & 0 & 3 & 8 & 11 & 72.73 & & \\
\hline
\end{tabular}


Table 6: Results of generalised linear models testing whether the species richness and the taxonomic distinctness of fish assemblages differed between the three seascape types, across a range of depths, at the island of Príncipe. The reference level is 'reef-sandy' transitions

\begin{tabular}{|c|c|c|c|c|}
\hline & Estimate & SE & $z$-value & $p$-value \\
\hline \multicolumn{5}{|c|}{ Species richness } \\
\hline Intercept & 2.59 & 0.14 & 18.33 & $<0.001$ \\
\hline Depth & -0.001 & 0.007 & -0.16 & 0.87 \\
\hline Habitat [reef-rhodolith] & -0.05 & 0.09 & -0.58 & 0.56 \\
\hline Habitat [rocky reefs] & 0.21 & 0.09 & 2.41 & 0.02 \\
\hline \multicolumn{5}{|c|}{ Taxonomic distinctness } \\
\hline Intercept & 1.79 & 0.15 & 12.32 & $<0.001$ \\
\hline Depth & -0.002 & 0.007 & -0.35 & 0.73 \\
\hline Habitat [reef-rhodolith] & 0.05 & 0.09 & 0.59 & 0.56 \\
\hline Habitat [rocky reefs] & -0.17 & 0.10 & -1.75 & 0.08 \\
\hline
\end{tabular}

and ecological studies in the Prícipe seascape types to effectively implement management practices to conserve local fish populations. In terms of fish species richness, previous surveys carried out in the shallow subtidal habitats of Príncipe (Tuya et al. 2018) and São Tomé (Maia et al. 2019) provided similar results. In addition, the levels of fish taxonomic biodiversity registered here were similar to those observed at other oceanic islands in the tropical eastern Atlantic (e.g. Cabo Verde Archipelago, 67 species: Freitas et al. 2019) and in the western Atlantic (e.g. Virgin Islands, 71 species: Mateo and Tobias 2007), but were lower compared with those recorded at islands in the Caribbean and in the Indo-Pacific (Allen 2008; Acero et al. 2019). Islands in the Gulf of Guinea, including Annobón, São Tomé and Príncipe, together with Cabo Verde, have been considered important global hotspots for the conservation of marine biodiversity (Roberts et al. 2002), with high levels of endemism ( 30\%: Floeter et al. 2008). This fact is probably linked to their geographic isolation (Floeter et al. 2008; Cowman et al. 2017), but also to their oceanographic connectivity with the tropical western Atlantic through the Equatorial Counter Current (Wirtz et al. 2007; Floeter et al. 2008; Hachich et al. 2015; Herrero-Barrencua et al. 2019). Additionally, the cool Benguela Current to the south limits the movement of tropical species from the Indian Ocean, whereas the cold waters of the northeastern Atlantic also limit the northern range of tropical fish species (Floeter et al. 2008; Almada et al. 2013; Maia et al. 2019). Other factors that might contribute to high fish diversity in the region relative to other eastern Atlantic areas include the large diversity of habitats, such as seagrasses (Alexandre et al. 2017) and mangroves, that can serve as nursery areas for fishes (Haroun et al. 2018). In the case of Príncipe, several locations with mangroves have been identified (e.g. at Praia Caixão, Praia Grande and Praia Salgada), and these appear to be remnants of more extensive mangrove forests that once existed along the island's coast (Haroun et al. 2018). Some fish species recorded in our study have also been described in the mangrove fish assemblages of the island (e.g. Pomadasys incisus: Haroun et al. 2018).

Differences in fish composition and assemblage structure between the three seascape types can be attributed to differences in the physical structure of the habitats. Indeed, variability in the qualitative and quantitative attributes associated with different habitat types can alter patterns in the composition and structure of biological assemblages, as has been reported for other habitat transitions in nearshore waters (Guidetti 2000; Gullström et al. 2008; Campbell et al. 2011; Tuya et al. 2011, 2019; Otero-Ferrer et al. 2019). For example, rocky reefs contain many structural elements (e.g. crevices, overhangs) which are available as refuges against predators (Almany 2004; Tuya et al. 2019). In contrast, higher rates of competition and predation between fish species are found in habitat transitions, often with less structural complexity and fewer niches (Richardson et al. 2017; Tuya et al. 2019), resulting in lower taxonomic diversity when compared with rocky reefs. High rates of predation have been observed among fishes living in habitat edges around rocky reefs (Frazer et al. 1991; Barros et al. 2001; Dorenbosch et al. 2005; Tuya et al. 2010, 2011). Similar 'edge' effects were also observed for fish assemblages inhabiting coral reef-seagrass transitions on the island of Zanzibar (western Indian Ocean) (Dorenbosch et al. 2005).

Despite rocky reefs showing greater taxonomic diversity (i.e. high species richness) in comparison with the habitat transitions, the phylogenetic diversity (i.e. taxonomic distinctness index) of fish assemblages was greater in both transition types than on rocky reefs. Other studies have similarly shown that communities with low species richness do not necessarily have a lesser taxonomic distinctness than communities with many species (Ellingsen et al. 2005; Tuya et al. 2019), whereas the species richness and taxonomic distinctness of nearshore fishes would normally be expected to behave in the same way (Bosch et al. 2017). The mixing of biotas associated with interconnected habitats at their edges tends to increase diversity (Magura 2002; Ries et al. 2004). In turn, the higher misclassification error values observed here for habitat transitions can be explained because fish assemblages inhabiting boundaries between two habitats display great variability in terms of composition and species abundances, as a result of the mixing of biotas (Barros et al. 2001; Ries et al. 2004; Tuya et al. 2011). Greater phylogenetic diversity at habitat transitions, however, might be connected with lower availability of resources, which translates into higher degrees of interspecific competition between close relatives (i.e. 'limiting similarity' hypothesis: Macarthur and Levins 1967). Several studies have stressed, in this sense, the importance of competitive exclusion in shaping local assemblages of marine fishes (e.g. Ford and Roberts 2019; Vallée et al. 2019).

Our results revealed a discrepancy in fish diversity patterns across nearshore seascape types that was dependent on the diversity metric employed-which can have conservation implications, as we could obtain a more holistic understanding of biodiversity, particularly in the context of functional or evolutionary lineages (Tucker et al. 2017; Mazel et al. 2018; Tuya et al. 2019). In particular, both the 'reefrhodolith bed' and the 'reef-sandy bottom' seascapes across Príncipe cannot be underestimated from a conservation perspective, because, despite their lower fish-species richness, these habitat transitions may accomplish other 
important ecological functions (e.g. nursery or foraging areas) for reef-associated fishes, as has been indicated previously (e.g. Ries et al. 2004; Campbell et al. 2011). Considering the long tradition of marine resource exploitation by artisanal fishers in São Tomé and Príncipe (Maia et al. 2018; Tuya et al. 2018), future management plans, including the placement of MPAs, should also consider the preservation of these habitat boundaries.

In summary, this study demonstrates that the composition, structure and diversity of the coastal fish assemblages of Príncipe varied between three nearshore seascape types. The two biodiversity dimensions (taxonomic and phylogenetic) assessed across the seascapes provided relevant information to better understand ecosystem functioning and community assemblages in the shallow waters surrounding this tropical island.

Acknowledgements - This work represents output of the BIO-Príncipe 2016 Scientific Expedition, promoted by the Regional Government of Príncipe through the UNESCO Biosphere Reserve, which was dependent for its success on the effort and assistance of local participants such as Estrela Matilde and Yodinei do Santos (Foundation Príncipe Trust). In addition, we thank Pedro Gomes (Scorpio Madeira diving centre), Marcial Cosme (University of Las Palmas) and Ann Bollen (Fauna and Flora International) for their assistance with SCUBA diving activities. Finally, we acknowledge the staff of Bom Bom Resort for their support during sampling, and A García Mendoza (University of Las Palmas) for his assistance with GIS.

\section{ORCID}

António Abreu: https://orcid.org/0000-0003-2686-714X

Néstor Guerra: https://orcid.org/0000-0003-0421-8456

R Haroun: https://orcid.org/0000-0003-1348-692X

Aketza Herrero-Barrencua: https://orcid.org/0000-0002-6764-9379

Francisco J Otero Ferrer: https://orcid.org/0000-0002-1328-9662

F Tuya: https://orcid.org/0000-0001-8316-5887

\section{References}

Abreu AD, Asensio MT, Cervera JL, Cosme M, Fuentes I, Gómez P et al. 2017. Final Report - Scientific Expedition BIO-Príncipe 2016. Technical report IU-ECOAQUA. Telde, Las Palmas de Gran Canaria: Universidad de Las Palmas de Gran Canaria.

Acero PA, Tavera JJ, Polanco FA, Bolaños-Cubillos N. 2019. Fish biodiversity in three northern islands of the Seaflower Biosphere Reserve (Colombian Caribbean). Frontiers in Marine Science 6: article 113.

Afonso P, Porteiro FM, Santos RS, Barreiros JP, Worms J, Wirtz P. 1999. Coastal marine fishes of São Tomé Island (Gulf of Guinea). Arquipélago - Life and Marine Sciences 17A: 65-92.

Alexandre A, Silva J, Ferreira R, Paulo D, Serrão EA, Santos R. 2017. First description of seagrass distribution and abundance in São Tomé and Príncipe. Aquatic Botany 142: 48-52.

Allen GR. 2008. Conservation hotspots of biodiversity and endemism for Indo-Pacific coral reef fishes. Aquatic Conservation: Marine and Freshwater Ecosystems 18: 541-556.

Almada VC, Toledo JMF, Brito A, Levy A, Floeter SR, Robalo $\mathrm{Jl}$ et al. 2013. Complex origins of the Lusitania biogeographic province and northeastern Atlantic fishes. Frontiers of Biogeography 5: 3-11.
Almany GR. 2004. Differential effects of habitat complexity, predators and competitors on abundance of juvenile and adult coral reef fishes. Oecologia 141: 105-113.

Amado-Filho GM, Maneveldt G, Manso RCC, Marins-Rosa BV, Pacheco MR, Guimarães SMPB. 2007. Structure of rhodolith beds from 4 to 55 meters deep along the southern coast of Espírito Santo State, Brazil. Ciencias Marinas 33: 399-410.

Anderson MJ, Willis TJ. 2003. Canonical analysis of principal coordinates: a useful method of constrained ordination for ecology. Ecology 84: 511-525.

Barros F, Underwood AJ, Lindegarth M. 2001. The influence of rocky reefs on structure of benthic macrofauna in nearby soft sediments. Estuarine, Coastal and Shelf Science 52: 191-199.

Bell RC, Drewes RC, Channing A, Gvozdık V, Kielgast J, Lötters S et al. 2015. Overseas dispersal of Hyperolius reed frogs from Central Africa to the oceanic islands of São Tomé and Príncipe. Journal of Biogeography 42: 65-75.

Bini LM, Diniz-Filho JA, Rangel T, Bastos RP, Pinto MP. 2006. Challenging Wallacean and Linnean shortfalls: knowledge gradients and conservation planning in a biodiversity hotspot. Diversity and Distributions 12: 475-482.

Bosch NE, Gonçalves JMS, Erzini K, Tuya F. 2017. "How" and "what" matters: sampling method affects biodiversity estimates of reef fishes. Ecology and Evolution 7: 4891-4906.

Cadotte MW, Davies JT, Regetz J, Kembel SW, Cleland E, Oakley TH. 2010. Phylogenetic diversity metrics for ecological communities: integrating species richness, abundance and evolutionary history. Ecology Letters 13: 96-105.

Cadotte MW, Dinnage R, Tilman D. 2012. Phylogenetic diversity promotes ecosystem stability. Ecology 93: S223-S233.

Campbell SJ, Kartawijaya T, Sabarini EK. 2011. Connectivity in reef fish assemblages between seagrass and coral reef habitats. Aquatic Biology 13: 65-77.

Carvalho S, Moura A, Cúrdia J, Cancela da Fonseca L, Santos MN. 2013. How complementary are epibenthic assemblages in artificial and nearby natural rocky reefs? Marine Environmental Research 92: 170-177.

Clarke KR, Warwick RM. 2001. Changes in marine communities: an approach to statistical analysis and interpretation (2nd edn). Plymouth, UK: PRIMER-E.

Cowman PF, Parravicini V, Kulbicki M, Floeter SR. 2017. The biogeography of tropical reef fishes: endemism and provinciality through time. Biological Reviews of the Cambridge Philosophical Society 92: 2112-2130.

Cresswell A, Edgar GJ, Stuart-Smith RD, Thomson R, Barrett NS, Johnson CR. 2017. Translating local benthic community structure to national biogenic reef habitat types. Global Ecology and Biogeography 26: 1112-125.

Daniel TF. 2010. Sciaphila ledermannii (Triuridaceae), a biogeographically significant holosaprophyte newly reported from Príncipe in the Gulf of Guinea. Proceedings of the California Academy of Sciences 61: 617-622.

de Figueiredo MAO, Santos de Menezes K, Costa-Paiva EM, Paiva PC, Ventura CRR. 2007. Evaluación experimental de rodolitos como sustratos vivos para la infauna en el Banco de Abrolhos, Brasil. Ciencias Marinas 33: 427-440.

Dorenbosch M, Grol MGG, Nagelkerken I, van der Velde G. 2005. Distribution of coral reef fishes along a coral reef-seagrass gradient: edge effects and habitat segregation. Marine Ecology Progress Series 299: 277-288.

Ellingsen KE, Clarke KR, Somerfield PJ, Warwick RM. 2005. Taxonomic distinctness as a measure of diversity applied over a large scale: the benthos of the Norwegian continental shelf. Journal of Animal Ecology 74: 1069-1079.

Espino F, González JA, Haroun R, Tuya F. 2015. Abundance and biomass of the parrotfish Sparisoma cretense in seagrass 
meadows: temporal and spatial differences between seagrass interiors and seagrass adjacent to reefs. Environmental Biology of Fishes 98: 121-133.

Floeter SR, Rocha LA, Robertson DR, Joyeux JC, Smith-Vaniz WF, Wirtz P, Bernardi G. 2008. Atlantic reef fish biogeography and evolution. Journal of Biogeography 35: 22-47.

Ford MD, Roberts JD. 2019. Evolutionary histories impart structure into marine fish heterospecific co-occurrence networks. Global Ecology and Biogeography 28: 1310-1324.

Foster MS, Amado-Filho GM, Kamenos NA, RiosmenaRodríguez R, Steller DL. 2013. Rhodoliths and rhodolith beds. Smithsonian Contributions to the Marine Sciences 39: 143-155.

Frazer TK, Lindeberg WJ, Stanton GR. 1991. Predation on sand dollars by gray triggerfish, Balistes capriscus, in the northeastern Gulf of Mexico. Bulletin of Marine Science 48: 159-164.

Freitas R, Mendes TC, Almeida C, Melo T, Villaça RC, Noguchi R et al. 2019. Reef fish and benthic community structures of the Santa Luzia Marine Reserve in the Cabo Verde islands, eastern central Atlantic Ocean. African Journal of Marine Science 41: 177-190.

Grall J, Le Loc'h F, Guyonnet B, Riera P. 2006. Community structure and food web based on stable isotopes $\left(\delta^{15} \mathrm{~N}\right.$ and $\delta^{13} \mathrm{C}$ ) analysis of a North Eastern Atlantic maerl bed. Journal of Experimental Marine Biology and Ecology 338: 1-15.

Guidetti P. 2000. Differences among fish assemblages associated with nearshore Posidonia oceanica seagrass beds, rockyalgal reefs and unvegetated sand habitats in the Adriatic Sea. Estuarine, Coastal and Shelf Science 50: 515-529.

Guisande González C. 2017. Package 'EcolndR'. Repository CRAN. Available at https://cran.r-project.org [accessed 4 August 2019].

Gullström M, Bodin M, Nilsson PG, Öhman MC. 2008. Seagrass structural complexity and landscape configuration as determinants of tropical fish assemblage composition. Marine Ecology Progress Series 363: 241-255.

Hachich NF, Bonsall MB, Arraut EM, Barneche DR, Lewinsohn TM, Floeter SR. 2015. Island biogeography: patterns of marine shallow-water organisms in the Atlantic Ocean. Journal of Biogeography 45: 1871-1882.

Haroun R, Herrero-Barrencua A, Abreu AD. 2018. Mangrove habitats in São Tomé and Príncipe (Gulf of Guinea, Africa): conservation and management status. In: Makowski C, Finkl C (eds), Threats to mangrove forests. Coastal Research Library vol. 25. Cham, Switzerland: Springer. pp 589-605.

Herrero-Barrencua A, Jaber JR, Abreu AD, Haroun R, Castro JJ. 2019. On the presence of Cantherhines macrocerus (Hollard, 1853 ) in the Príncipe Island (Gulf of Guinea). Cahiers de Biologie Marine 60: 289-292.

Hortal J, de Bello F, Diniz-Filho JAF, Lewinsohn TM, Lobo JM, Ladle RJ. 2015. Seven shortfalls that beset large-scale knowledge of biodiversity. Annual Review of Ecology, Evolution, and Systematics 46: 523-549.

Jones PJ. 1994. Biodiversity in the Gulf of Guinea: an overview. Biodiversity and Conservation 3: 772-784.

Lee JSF, Berejikian BA, Rust MB, Massee K, Wright T, Brakensiek K et al. 2011. Movements of hatchery-reared lingcod released on rocky reefs in Puget Sound. Environmental Biology of Fishes 92: 437-445.

Macarthur R, Levins R. 1967. The limiting similarity, convergence, and divergence of coexisting species. The American Naturalist 101: 377-385.

Magura T. 2002. Carabids and forest edge: spatial pattern and edge effect. Forest Ecology and Management 157: 23-37.

Maia HA, Morais RA, Siqueira AC, Hanazaki N, Floeter SR, Bender MG. 2018. Shifting baselines among traditional fishers in São Tomé and Príncipe islands, Gulf of Guinea. Ocean and Coastal Management 154: 133-142.
Maia HA, Morais RA, Quimbayo JP, Dias MS, Sampaio CLS, Horta PA et al. 2019. Spatial patterns and drivers of fish and benthic reef communities at São Tomé Island, Tropical Eastern Atlantic. Marine Ecology (Berlin) 39: e12520.

Mateo I, Tobias WJ. 2007. A comparison of fish assemblages among five habitat types within a Caribbean lagoonal system. Gulf and Caribbean Research 19: 21-31.

Mazel F, Pennell MW, Cadotte MW, Diaz S, Dalla Riva GV, Grenyer R et al. 2018. Prioritizing phylogenetic diversity captures functional diversity unreliably. Nature Communications 9: article 2888.

Miller EC, Sellas AB, Drewes RC. 2012. A new species of Hemidactylus (Squamata: Gekkonidae) from Príncipe Island, Gulf of Guinea, West Africa with comments on the AfricanAtlantic clade of Hemidactylus geckos. African Journal of Herpetology 61: 40-57.

Otero-Ferrer F, González JA, Freitas M, Araújo R, Azevedo JMN, Holt WV et al. 2017. When natural history collections reveal secrets on data deficient threatened species: Atlantic seahorses as a case study. Biodiversity and Conservation 26: 2791-2802.

Otero-Ferrer F, Mannarà E, Cosme A, Falace A, Montiel-Nelson JA, Espino $F$ et al. 2019. Early-faunal colonization patterns of discrete habitat units: a case study with rhodolith-associated vagile macrofauna. Estuarine, Coastal and Shelf Science 218: 9-22.

Otero-Ferrer F, Cosme A, Tuya F, Espino F, Haroun R. 2020. Effect of depth and seasonality on the functioning of rhodolith seabeds. Estuarine, Coastal and Shelf Science 235: article 106579.

Pereira-Filho GH, Veras PC, Francini-Filho RB, Moura RL, Pinheiro HT, Gibran FZ et al. 2015. Effects of the sand tilefish Malacanthus plumieri on the structure and dynamics of a rhodolith bed in the Fernando de Noronha Archipelago, tropical West Atlantic. Marine Ecology Progress Series 541: 65-73.

$\mathrm{R}$ Core Team. 2016. R: a language and environment for statistical computing. Vienna, Austria: R Foundation for Statistical Computing.

Richardson LE, Graham NAJ, Pratchett MS, Hoey AS. 2017. Structural complexity mediates functional structure of reef fish assemblages among coral habitats. Environmental Biology of Fishes 100: 193-207.

Ries L, Fletcher RJ, Battin J, Sisk TD. 2004. Ecological responses to habitat edges: mechanisms, models, and variability explained. Annual Review of Ecology, Evolution, and Systematics 35: 491-522.

Roberts CM, McClean CJ, Veron JEN, Hawkins JP, Allen GR, McAllister DE et al. 2002. Marine biodiversity hotspots and conservation priorities for tropical reefs. Science 295: 1280-1284.

Rogers SI, Clarke KR, Reynolds JD. 1999. The taxonomic distinctness of coastal bottom-dwelling fish communities of the North-east Atlantic. Journal of Animal Ecology 68: 769-782.

Spalding MD, Fox HE, Allen GR, Davidson N, Ferdaña ZA, Finlayson $\mathrm{M}$ et al. 2007. Marine ecoregions of the world: a bioregionalization of coastal and shelf areas. BioScience 57: 573-583.

Steller DL, Riosmena-Rodríguez R, Foster MS, Roberts CA. 2003. Rhodolith bed diversity in the Gulf of California: the importance of rhodolith structure and consequences of disturbance. Aquatic Conservation: Marine and Freshwater Ecosystems 13: S5-S20.

Tucker CM, Cadotte MW, Carvalho SB, Davies TJ, Ferrier S, Fritz SA et al. 2017. A guide to phylogenetic metrics for conservation, community ecology and macroecology. Biological Reviews of the Cambridge Philosophical Society 92: 698-715.

Tuya F, Vanderklift MA, Hyndes GA, Wernberg T, Thomsen MS, Hanson C. 2010. Proximity to rocky reefs alters the balance between positive and negative effects on seagrass fauna. Marine Ecology Progress Series 405: 175-186. 
Tuya F, Vanderklift MA, Wernberg T, Thomsen MS. 2011. Gradients in the number of species at reef-seagrass ecotones explained by gradients in abundance. PLoS ONE 6: e20190.

Tuya F, Herrero-Barrencua A, Bosch N, Abreu A, Haroun R. 2018. Reef fishes at a remote tropical island (Príncipe Island, Gulf of Guinea): disentangling taxonomic, functional and phylogenetic diversity patterns with depth. Marine and Freshwater Research 69: 395-402.

Tuya F, Asensio M, Bosch N, García A, Navarro A. 2019. Partitioning multiple diversity dimensions of nearshore fish assemblages within a coastal seascape. Hydrobiologia 834: 87-102.

Valentine JF, Heck KL, Blackmon D, Goecker ME, Christian J, Kroutil RM et al. 2008. Exploited species impacts on trophic linkages along reef-seagrass interfaces in the Florida Keys. Ecological Applications 18: 1501-1515.

Vallée V, Villanueva MC, Blanchard F. 2019. Functional richness and turnover patterns reveal assembly rules structuring marine fish communities on the continental shelf of French Guiana. Marine Ecology Progress Series 630: 183-195.
Vasco-Rodrigues N, Bertoncini A, Fontes J. 2018. Peixes marinhos costeiros de São Tomé e Príncipe (Coastal marine fishes of São Tomé and Príncipe). Lisbon, Portugal: Flying Sharks.

Venables WN, Ripley BD. 2002. Modern applied statistics with S (4th edn). New York: Springer.

Wang Y, Naumann U, Wright ST, Warton DI. 2012. mvabund: an $\mathrm{R}$ package for model-based analysis of multivariate abundance data. Methods in Ecology and Evolution 3: 471-474.

Whittaker RJ, Araújo MB, Jepson P, Ladle RJ, Watson JEM, Willis KJ. 2005. Conservation biogeography: assessment and prospect. Diversity and Distributions 11: 3-23.

Wirtz P, Ferreira CEL, Floeter SR, Fricke R, Gasparini JL, Iwamoto T et al. 2007. Coastal fishes of São Tomé and Príncipe islands, Gulf of Guinea (Eastern Atlantic Ocean) - an update. Zootaxa 1523: 1-48.

Wong MC, Kay LM. 2019. Partial congruence in habitat patterns for taxonomic and functional diversity of fish assemblages in seagrass ecosystems. Marine Biology 166: article 46. 